\title{
Prevalence of respiratory pathogens in nasal swabs from horses with acute respiratory disease in Belgium
}

\author{
Prevalentie van respiratoire pathogenen in neusswabs van paarden met acute \\ ademhalingsstoornissen in België
}

\author{
${ }^{1}$ B. Broux, ${ }^{2}$ A. Gryspeerdt, ${ }^{3} \mathrm{H}$. Amory, ${ }^{4}$ T. Frippiat, ${ }^{1}$ B. Pardon, ${ }^{5} \mathrm{~F}$. Gasthuys, ${ }^{6} \mathrm{~L}$. Legrand, \\ ${ }^{1}$ P. Deprez
}

${ }^{1}$ Departement of Large Animal Internal Medicine, Faculty of Veterinary Medicine, Ghent University, Salisburylaan 133, 9820 Merelbeke, Belgium

${ }^{2}$ Dierengezondheidszorg Vlaanderen, Deinse Horsweg 1, 9031 Drongen, Belgium

${ }^{3}$ Departement Clinique des Animaux de Compagnie et des Equides, Faculté de Médecine Vétérinaire, Liège University, Avenue de Cureghem 2, Liège, Belgium

${ }^{4}$ Equine Sports Medicine, PO box 46, 1270 AA Huizen, the Netherlands

${ }^{5}$ Departement of Large Animal Surgery and Anesthesiology, Faculty of Veterinary Medicine, Ghent University, Salisburylaan 133, 9820 Merelbeke, Belgium

${ }^{6}$ LABÉO Frank Duncombe, EA4655 U2RM Université Caen Basse-Normandie, Fondation Hippolia, 14053 Caen, France

Barbara.Broux@UGent.be

\section{$\Lambda_{\text {bstract }}$}

Contagious respiratory infections are an important cause of respiratory disease in horses, resulting in impaired pulmonary function, poor performance and sometimes severe illness. Although bacterial infections are often suspected to be involved, viruses are frequently overlooked and are an underestimated cause of respiratory disease outbreaks in horses. In this study, nasal swabs of 103 horses with acute symptoms of respiratory disease were analyzed for the presence of 13 different respiratory pathogens. Gamma herpesviruses were the most commonly detected, with $60 \%$ of the samples being positive, followed by streptococcus equi subsp. zooepidemicus infection (30\%). Rhinovirus B, streptococcus equi subsp. equi, adenovirus 1 and EHV-4 were more rarely detected. Further research is necessary to correctly interpret the importance of gamma herpesviruses in horses, for example by screening a healthy control population. National surveillance of respiratory viruses in horses by PCR analysis on nasal swabs might be a useful, earlywarning system for viral epidemics.

\section{SAMENVATTING}

Infectieuze aandoeningen zijn een belangrijke oorzaak van ademhalingsproblemen bij paarden. Ze kunnen aanleiding geven tot een verstoorde longfunctie, verminderde prestaties en soms ernstige klinische ziekte. Hoewel meestal bacteriële infecties vermoed worden, zijn virussen een onderschatte oorzaak van besmettelijke ademhalingsinfecties bij paarden. In deze studie werden neusswabs genomen bij 103 paarden met symptomen van acute ademhalingsinfectie en gescreend op de aanwezigheid van 13 verschillende equine ademhalingspathogenen. Gammaherpesvirussen waren, met $60 \%$ positieve stalen, de meest gedetecteerde pathogenen, gevolgd door streptococcus equi subsp. zooepidemicus infecties (30\%). Rhinovirus B, streptococcus equi subsp. equi, adenovirus 1 en EHV-4 werden minder frequent gevonden. Verder onderzoek is nodig om het belang van gammaherpesvirussen bij het paard correct te interpreteren. Nationale surveillance van ademhalingsvirussen bij paarden door middel van PCR-analyse op neusswabs zou een nuttig waarschuwingssysteem voor dreigende virale epidemieën kunnen zijn. 


\section{INTRODUCTION}

Respiratory problems are among the most important disorders limiting the athletic performance of the horse. Consequently, early detection and adequate treatment are essential to maximize the chances of recovery and to reduce economic and performance losses (Van Erck-Westergren et al., 2013). Infectious diseases are frequently involved in clinical or subclinical respiratory disorders. Field studies on viral antigens in the respiratory tract are limited in horses, and hence, the prevalence of respiratory pathogens is unknown in many countries, including Belgium. Identification of etiologic agents requires laboratory analysis on samples from the respiratory tract. Whereas sampling of the lower airways is not always straightforward in first-line clinical practice, the use of nasal swabs offers a more achievable alternative, especially for viruses, as recently documented in a national surveillance program for respiratory viruses in cattle in Ireland (O'Neill et al., 2014). The objective of the present survey was to determine the nasal prevalence of infectious respiratory agents in horses with acute respiratory disease in Belgium.

\section{MATERIALS AND METHODS}

Belgian equine veterinarians were requested to sample horses showing clinical signs suggestive of an acute respiratory disease. Inclusion criteria for the study were acute ( $<3$ days) onset of fever (rectal temperature $>38.5^{\circ} \mathrm{C}$ ) and at least one of the following other criteria: nasal discharge, cough, lymphadenopathy or an obvious contagious character of the occurring disease ( $>$ two horses affected). No more than two horses within the same premises were sampled. Dry nasal cotton swabs were advanced deep $(>30 \mathrm{~cm})$ into the ventral nasal conchae. The swabs were placed in a viral transport medium and kept cooled at $8^{\circ} \mathrm{C}$ during transport and prior to analysis. Samples were analyzed for 13 different respiratory pathogens (equine influenza virus (EIV), equine herpesvirus (EHV) 1, 2, 4 and 5, equine arteritis virus (EAV), adenovirus 1 and 2, coronavirus, equine rhinitis virus A (ERAV) and B (ERBV), Streptococcus equi subsp. zooepidemicus and Streptococcus equi subsp. equi). Briefly, nucleic acid was extracted from $140 \mu \mathrm{L}$ of fluids with the QIAamp RNA minikit (Qiagen, Les Ulis, France) according to the manufacturer's instructions. The final elution was $50 \mu \mathrm{L}$. The different PCRs were performed after development and validation as described previously (Hue et al., 2014). All the qPCRs used were characterized (limit of detection method, limit of quantification method, limit of detection PCR limit of quantification PCR) and validated for the use in horses according to the French AFNORnorm U47600 and as described for EHV2 by Hue et al. (2015).

\section{RESULTS}

Between January and September 2014, a total of 103 horses in 95 suspected outbreaks of acute contagious respiratory disease were sampled. Other clinical signs in addition to fever, were nasal discharge (60/103, 58\%), cough $(33 / 103,32 \%)$ and lymphadenopathy $(24 / 103,23 \%)$. An overview of the PCR results is shown in Table 1 . In $71 \%$ of cases, a positive result was obtained. EHV2 and EHV5 were the most commonly detected pathogens with $60 \%$ of the horses positive for EHV2, EHV5 or both (62/103). Mixed infections were present in $45 \%$ of the horses (46/103), mostly involving EHV2 and EHV5.

\section{DISCUSSION}

The objective of the present study was to determine the prevalence of infectious respiratory agents in horses with acute respiratory disease in Belgium. This type of prevalence studies is biased by the fact that a random sampling is difficult to perform in practice. Furthermore, samples were taken by first-line practitioners, so protocol compliance is difficult to evaluate. Incorrect sample collection and transport may lead to false negative results. Therefore, the results on the convenience sample of the present study should be interpreted as indicative but not representative for the whole Belgian equine population. The use of PCR on nasal swabs provided an accessible diagnostic procedure for first-opinion practice. The envisaged amount of samples was obtained within a reasonable timeframe, which is an essential prerequisite for any surveillance program for respiratory pathogens.

The present study provided interesting results on the relative importance of respiratory viruses and bacteria affecting the upper airways in horses. The most important observation was the abundant presence of equine gamma herpesviruses (EHV2 and EHV5). Serological studies demonstrated that EHV2 is endemic in equine populations worldwide, with approximately $90 \%$ of horses being seropositive, but the nasal presence of viral DNA in healthy as well as in diseased horses is scarcely documented (Nordengrahn et al., 2002). Because of the high number of seropositive horses and the lack of serological differences between healthy and diseased horses, opinions vary as to the true pathogenicity of EHV2. Since EHV2 is frequently detected in combination with other respiratory pathogens, which was confirmed in the present study, the suggestion has been made that EHV2 can predispose horses to other viral and bacterial infections (Nordengrahn et al., 1996). However, EHV2 was the sole pathogen found in nine horses in the present study, which might suggest primary pathogenicity of EHV2. For EHV5, seroprevalence studies show conflicting results (Akkutay et al., 2014; Nordengrahn et al., 
Table 1. Respiratory pathogens detected by PCR performed on nasal swabs of $\mathbf{1 0 3}$ horses with acute respiratory disease in Belgium (2014). Data are shown both on herd level (95 different herds) as on horse level (103 individual horses).

\begin{tabular}{lccc}
\hline Pathogen & Single Infections & Mixed Infections & Total \\
Negative & $/$ & $/$ & $29 \%$ \\
& $/$ & $/$ & $(30 / 103)$ \\
\hline EIV & $0 \%$ & $0 \%$ & $0 \%$ \\
& $(0 / 103)$ & $0 / 103)$ & $(0 / 103)$ \\
EHV1 & $0 \%$ & $1 \%$ & $1 \%$ \\
& $(0 / 103)$ & $(1 / 103)$ & $(1 / 103)$ \\
EHV4 & $1 \%$ & $6 \%$ & $7 \%$ \\
& $(1 / 103)$ & $(6 / 103)$ & $(7 / 103)$ \\
EHV2 & $9 \%$ & $39 \%$ & $48 \%$ \\
& $(9 / 103)$ & $(40 / 103)$ & $(49 / 103)$ \\
EHV5 & $11 \%$ & $43 \%$ & $53 \%$ \\
& $(11 / 103)$ & $(44 / 103)$ & $(55 / 103)$ \\
EAV & $0 \%$ & $0 \%$ & $(0 / 103)$ \\
& $(0 / 103)$ & $(0 / 103)$ & $4 \%$ \\
Adenovirus 1 & $0 \%$ & $4 \%$ & $(4 / 103)$ \\
& $(0 / 103)$ & $(4 / 103)$ & $0 \%$ \\
Adenovirus 2 & $0 \%$ & $0 \%$ & $(0 / 103)$ \\
& $(0 / 103)$ & $(0 / 103)$ & $0 \%$ \\
Coronavirus & $0 \%$ & $0 \%$ & $(0 / 103)$ \\
& $(0 / 103)$ & $(0 / 103)$ & $15 \%$ \\
ERBV & $2 \%$ & $13 \%$ & $(15 / 103)$ \\
& $(2 / 103)$ & $(13 / 103)$ & $0 \%$ \\
ERAV & $0 \%$ & $0 \%$ & $(0 / 103)$ \\
& $(0 / 103)$ & $(0 / 103)$ & $30 \%$ \\
S. equi subsp. zooepidemicus & $4 \%$ & $26 \%$ & $(31 / 103)$ \\
S. equi subsp. equi & $(4 / 103)$ & $(27 / 103)$ & $(13 \% / 95)$ \\
& $0 \%$ & $13 \%$ & $(13 / 103)$ \\
\hline
\end{tabular}

EIV: equine influenza virus; EHV: equine herpesvirus; EAV: equine arteritis virus; ERBV: equine rhinitis virus B; ERAV: equine rhinitis virus $\mathrm{A}$

2002). In the present study, EHV5 was detected in almost half of the horses showing acute respiratory signs and often in combination with EHV2 or other pathogens. However, EHV5 was the sole pathogen in 11 of the included horses. EHV5 has been isolated from healthy horses as well as from horses with a variety of respiratory diseases, making its clinical importance difficult to interpret (Dunowska et al., 1999; Nordengrahn et al., 2002). Recently, EHV5 has often been mentioned in relation to equine multinodular pulmonary disease. None of the horses of the present study developed lesions compatible with this condition. A second interesting finding was the absence of EIV in the studied population. Possible explanations might be the widespread vaccination against EIV in Belgium and the narrow timeframe for virus detection, namely 24 hours after the onset of clinical signs (Gilkerson et al., 2015; Kirkland et al., 2011). For respiratory bacteria, the frequent presence of Streptocuccus equi subsp. zooepidemicus (30\%) is difficult to interpret, since this opportunistic pathogen can be a normal inhabitant of the upper airways (Lindahl et al., 2013). However, the presence of Streptococcus equi subsp. equi is always significant and warrants immediate action to prevent spread to other horses.

Next to the difficulties of random sampling, another important limitation of this study was the lack of a control group for prevalence determination in healthy horses. More studies and serological surveys would be very useful to compare prevalences of this subset of respiratory pathogens in healthy versus ill horses, in order to gain more insight into the true pathogenicity of these agents.

\section{CONCLUSION}

The present study indicates that equine gamma herpesviruses are most frequently detected in nasal samples of horses with acute respiratory disease in Belgium. As recommended for bovine respiratory diseases in Belgium and already applied in France and the UK for equine respiratory infections (Legrand et al., 2013; O'Neill et al., 2014; Pardon, 2014; Pardon et al., 2011), national surveillance of respiratory viruses in horses by PCR analysis on nasal swabs might 
be a useful, early-warning system for viral epidemics. However, more large scale surveillance studies are needed both in healthy and sick horses, to evaluate the value of nasal swab PCR analysis results in a population of horses for early detection of threatening epidemics. Most probably, longitudinal studies with follow-up in time will be needed for this purpose.

\section{ACKNOWLEDGEMENTS}

This project was coordinated by Equi Focus Point Belgium, in cooperation with Dierengezondheidszorg Vlaanderen and Arsia Wallonië. We thank Zoetis Belgium, the Belgian Horse Confederation (BCP-CBC) and the Belgian Equine Practitioner Society (BEPS) for their financial support.

\section{LITERATURE}

Akkutay, A.Z., Osterrieder, N., Damiani, A., Tischer, B.K., Borchers, K., Alkan, F. (2014). Prevalence of equine gammaherpesviruses on breeding farms in Turkey and development of a TaqMan MGB real-time PCR to detect equine herpesvirus 5 (EHV-5). Archives of Virology 159, 2989-2995.

Dunowska, M., Meers, J., Wilks, C.R., 1999. Isolation of equine herpesvirus type 5 in New Zealand. New Zealand Veterinary Journal 47, 44-46.

Gilkerson, J.R., Bailey, K.E., Diaz-Mendez, A., Hartley, C.A. (2015). Update on viral diseases of the equine respiratory tract. The Veterinary Clinics of North America. Equine Practice 31, 91-104.

Hue, E.S., Fortier, G.D., Fortier, C.I., Leon, A.M., Richard, E.A., Legrand, L.J., Pronost, S.L. (2014). Detection and quantitation of equid gammaherpesviruses (EHV-2, EHV-5) in nasal swabs using an accredited standardised quantitative PCR method. Journal of Virological Methods 198, 18-25.

Hue, E.S., Fortier, C.I., Laurent, A., Quesnelle, Y., Fortier G.D., Legrand L.J., Pronost, S.L . (2015). Development and validation of a quantitative PCR method for equid herpesvirus-2 diagnostics in respiratory fluids. Journal of Visualized Experiments 109, 53-67.

Kirkland, P.D., Davis, R.J., Gu, X., Frost, M. (2011). Application of high-throughput systems for the rapid detection of DNA and RNA viruses during the Australian equine influenza outbreak. Australian Veterinary Journal 89, 38-39.

Legrand, L.J., Pitel, P.H., Marcillaud-Pitel, C.J., Cullinane, A.A., Courouce, A.M., Fortier, G.D., Freymuth, F.L., Pronost, S.L. (2013). Surveillance of equine influenza viruses through the RESPE network in France from November 2005 to October 2010. Equine Veterinary Journal 45, 776-783.

Lindahl, S.B., Aspan, A., Baverud, V., Paillot, R., Pringle, J., Rash, N.L., Soderlund, R., Waller, A.S. (2013). Outbreak of upper respiratory disease in horses caused by Streptococcus equi subsp. zooepidemicus ST-24. Veterinary Microbiology 166, 281-285.

Nordengrahn, A., Merza, M., Ros, C., Lindholmc, A., Palfl, V., Hannant, D., Belak, S. (2002). Prevalence of equine herpesvirus types 2 and 5 in horse populations by using type-specific PCR assays. Veterinary Research 33, 251259.

Nordengrahn, A., Rusvai, M., Merza, M., Ekstrom, J., Morein, B., Belak, S. (1996). Equine herpesvirus type 2 (EHV-2) as a predisposing factor for Rhodococcus equi pneumonia in foals: prevention of the bifactorial disease with EHV-2 immunostimulating complexes. Veterinary Microbiology 51, 55-68.

O'Neill, R., Mooney, J., Connaghan, E., Furphy, C., Graham, D.A. (2014). Patterns of detection of respiratory viruses in nasal swabs from calves in Ireland: a retrospective study. Veterinary Record 175, 351.

Pardon, B. (2014). Developing an early warning system for bovine respiratory disease. Veterinary Record 175, 349350.

Pardon, B., De Bleecker, K., Dewulf, J., Callens, J., Boyen, F., Catry, B., Deprez, P. (2011). Prevalence of respiratory pathogens in diseased, non-vaccinated, routinely medicated veal calves. Veterinary Record 169, 278.

Van Erck-Westergren, E., Franklin, S.H., Bayly, W.M. (2013). Respiratory diseases and their effects on respiratory function and exercise capacity. Equine Veterinary Journal 45, 376-387. 